\title{
External Debt \& Economic Growth: Case of Tunisia
}

\author{
Zaghdoudi Khemais $^{1}$, Mezni Mohamed ${ }^{1} \&$ Djebali Nesrine $^{1}$ \\ ${ }^{1}$ Faculty of Law, Economics and Management of Jendouba, University of Jendouba, Tunisia \\ Correspondence: Mezni Mohamed, Faculty of Law, Economics and Management of Jendouba, University of \\ Jendouba, Tunisia. Tel: 216-27-437-374. E-mail: meznimohamed25@yahoo.fr
}

Received: March 14, 2016

Accepted: April 13, 2016

Online Published: May 25, 2016

doi:10.5539/ijef.v8n6p129

URL: http://dx.doi.org/10.5539/ijef.v8n6p129

\begin{abstract}
The main objective of this paper is to explore the influence of external debt (measured by two indicators that are outstanding debt and debt service in relation to exports of goods and services) on investment and economic growth in Tunisia during a period of 51 years which runs from 1961 to 2011, using vector autoregressive model (VAR). The empirical results show that, in the short term, outstanding debt and debt service in relation to exports of goods and services do not cause economic growth. In the long term, the external debt service is detrimental to Tunisian economy. In Tunisia, the problem is not a debt problem in itself, but the problem concerns the use of this debt. External debt is allocated to activities with both low added value and profitability. In the absence of a clear industrial policy, these activities are traditional activities that do not create wealth, correspond with competitive advantages of the country and employ the qualified workforce. Therefore, the unemployment rate of graduates increases regularly. Furthermore, a significant share of borrowed funds are intended to pay the salaries of the public sector, that have represented more than a third of the state budget in recent years. Then, external debt did not help the country to develop because those salaries went into consumption of some imported goods that are not produced in the home market.
\end{abstract}

Keywords: external debt, investment, economic growth, Tunisia

\section{Introduction}

The relationship between external debt and economic growth has been analyzed by numerous authors and their results have provided conflicting conclusions. In fact, some studies found that external debt has a positive impact on economic growth (Moga et al., 2016; Evan et al., 2015; Zaman \& Arslan, 2014; Abdelhadi, 2013; Uzun et al., 2012; Karagol \& Erda, 2004 etc.). While others concluded that the external debt is detrimental to economic growth (Bolanle et al., 2015; Ajayi \& Oke, 2012; Athens \& Malik, 2012; Atique \& Kamran, 2012; Safdari \& Mehrizi, 2011; Cordella et al., 2005; Patillo et al., 2004 etc.).

These different results show that the relationship between external debt and economic growth has not been unanimous. Moreover, most of the available studies analyzed this relationship without taking into consideration the specificities of the country and especially the destination of external debt.

Therefore, the motivation of our paper is to investigate the effect of external debt on economic growth for the case of Tunisia. Tunisia is an interesting case study since, in recent years, its economic growth rate has gone down despite the increase of the external debt ratio. Particularly, in the last five years, the external debt was around 5000MDT every year. This exceeds the resources devoted to investment. In the annual budgets, the state devotes a large amount of this debt to finance the national economy. Or, we found that the country's economic growth rate drops considerably. It is equal to $2.3 \%$ in 2014 , which is below the rate of global economic growth (3.4\%) and the rate of growth in emerging and developing countries (4.6\%).

Compared to other previous works, in this article, we are firstly aiming at empirically showing the influence of debt on economic growth of Tunisia, and then trying to explain why external debt is detrimental to Tunisia? To this end, our dataset covers the period from 1961 to 2011 and the model used is the vector autoregressive model (VAR).

The structure of this paper is presented as follows. In section 2, we present the literature review. We have advanced two hypotheses to be tested in order to detect the impact of external debt on economic growth of Tunisia. The data and the model specification are presented in section 3. The results of the empirical investigation are given in section 4 . Finally, section 5 is devoted to discussion. 


\section{Literature Review}

The impact of external debt on economic growth has been studied by many authors that have found opposite results. In fact, some of them showed that there is a positive relationship between external debt and economic growth. The external debt can boost the country's economic growth if it is used efficiently. While, other authors supported the idea that the external debt has a negative impact on economic growth, due to the inappropriate allocation of resources.

\section{Hypothesis 1: Positive impact of external debt on economic growth}

Moga et al. (2016) examined the relationship between external debt and economic growth of Tanzania for a period from 1971 to 2011. Their results support the idea that debt helps to promote investment and stimulate long-term economic growth. Based on three countries (Malaysia, Thailand and Philippines), Evan et al. (2015) studied the relationship between external debt and economic growth over 50 years. They found that the accumulation of external debt stimulates positively economic growth of these countries provided that it is accompanied by careful monitoring to avoid the risk of debt distress and misallocation. Zaman and Arslan (2014) showed that, in the short term, external debt plays a major role in promoting Pakistan's economic activity. Abdelhadi (2013) found a positive impact of external debt on the economic growth of the Jordan for a period of 22 years from 1990 to 2011 since an important portion of this debt was devoted to improve the educational system and the country's infrastructure. Uzun et al. (2012) examined also the relationship between GDP per capita growth rates and outside debt to GDP for a sample of transition countries in a period from 1991 to 2009. Their results show that external debt encourages long-term growth. During a period of 39 years which runs from 1958 to 1996, Karagol and Erda (2004) showed the presence of a positive relationship between external debt and economic growth for the case of Turkey.

\section{Hypothesis 2: Negative impact of external debt on economic growth}

Bolanle et al. (2015) analyzed the influence of external debt on economic growth and foreign direct investment for the case of Nigerian economy. Their results support the idea that external debt is negatively but insignificantly linked to economic growth while foreign direct investment is also negatively but significantly related. Ajayi and Okemo (2012) found also a negative impact of external debt on economic growth in Nigeria since a significant share of borrowed funds are devoted to pay the salaries of the public sector. This country specifies a significant share of borrowed resources to military expenses to ensure the stability of the country, which suffers from internal conflicts. Atique and Kamran (2012) showed the existence of a negative impact of external debt on Pakistan's economic growth during the period that covers 31 years from 1980 to 2010. This result is explained by inappropriate policies makers, who do not favor the financing of productive investment. Safdari and Mehrizi (2011) studied the impact of external debt on economic growth for a period which runs from 1974 to 2007. They showed that the debt had a negative effect on gross domestic product, imports and economic growth. Cordella et al. (2005) examined how external debt-economic growth relationship varies with debt levels using a panel of 79 developing countries over the period 1970-2002. The study shows the existence of a negative relationship between debt and growth at intermediate levels of debt, but not with very low debt levels. Patillo et al. (2004) used a set of panel data for the period 1969-1998 to examine the relationship between external debt and economic growth for some developing countries. The empirical results reveal that the accumulation of foreign debt has a negative impact on economic growth and private investment. They concluded that the average of economic growth for countries with high debt growth decreases by about one percent.

\section{Data and Model Specification}

\subsection{Presentation of the Vector Autoregressive Model (VAR)}

In our econometric study, we use the VAR model that is a statistical model developed early by Christopher Sims in 1980. The importance of this model is summed up in its power to capture the interdependencies between multiple time series.

\section{- VAR model}

First, Sims (1980) developed a model to overcome the shortcomings of Keynesian macroeconomic models which are mainly:

- The excessive restrictions on the parameters compared to what the theory predicts, i.e exogeneity of some variables is postulated without being formally tested (Gosse \& Guillaumin, 2011).

- The absence of the test on the causal relationship.

- The inadequate treatment of agents' expectations. 
VAR representation is based on the assumption that the evolution of the economy can be well approximated by the description of the dynamic behavior of a vector of several variables linearly dependent of their past (Sims, 1980).

\section{- VAR Estimation}

The estimate of a VAR process (P) can be done either by the method of least square ordinary (OLS) or the maximum likelihood method. OLS is no longer valid since there are constraints on the parameters (Lardic \& Mignon, 2002). The use of the maximum likelihood method is the main method used to provide reliable estimates allowing to obtain variance- covariance matrix (Hamilton, 1994).

\section{- $\quad$ The choice of delays}

Among the most important steps in the estimation process, there is the choice of delays, since insufficient number of delays causes the loss of information on the studied process. In other words, a high number of delays increases the number of parameters to estimate and leads to the reduction of the degree of freedom of the process (Gosse et al. 2011).

\section{- $\quad$ Prediction}

Good prediction is the essential purpose of the VAR process. According to initial works of Sims (1980), predictions made from the VAR process are better than those deducted from forecasting models.

\section{- $\quad$ Causality and impulse analysis (identification of the shock)}

- Causality

There are many definitions of causality such as Sims causality, Pierce and Haugh causality and Granger causality. In our econometric study, we will refer to the causality of Granger (1969) to detect the causal relationship between debt and growth variables.

- Pulse Analysis (identification shocks)

Among the most important steps in the VAR analysis, we find the impulse responses that determine the impact of a shock related to the evolution of a variable on other model variables.

Granger causality or non causality will play a definite role when introduced in the model, since it specifies that the shocks associated with a variable don't possibly have any influence on other variables in the model (Lubrano, 2007).

\subsection{Presentation of the Model}

The model to be estimated is defined as follows:

$$
\mathrm{Y}_{\mathrm{it}}=\alpha+\beta \mathrm{Y}_{\mathrm{i}, \mathrm{t}-1}+\sum_{\mathrm{j}}^{\mathrm{k}}+X i t j+D i t i
$$

Where:

- Yit: The logarithm of real GDP.

- Xitj: The Vector of control variables.

- Diti: The various indicators of external debt

3.2.1 Dependent Variable

Real GDP is the growth variable used heavily in different empirical works studying the factors of economic growth.

\subsubsection{Explanatory Variables}

\subsubsection{External Debt Variables}

In this paper, external debt is measured by two indicators which are outstanding debt as a percentage of GDP and debt service in relation to exports of goods and services.

Outstanding debt is the stock of debt as a percentage of GDP. This ratio is used to detect the debt effect on investment and growth. Similarly, a high debt service may discourage investment. Calvo (2003) shows that debt service constitutes a tax on future production and also a source of discouragement for investment.

\subsubsection{Control Variables}

- $\quad$ The investment rate as percentage of GDP 
Several authors show the importance of investment for growth. For example, Ojjo and Oshikaya (1995) found a positive effect of the investment on economic growth.

- Trade openness

A good trade openness of an economy attracts domestic and foreign investors, improves productivity, allows technology transfer, facilitates new markets and increases foreign currencies. The country will thus be able to repay the debt service (Carrierie et al., 2003).

- $\quad$ The rate of schooling

The rate of schooling is the percentage of young people of a given age in school compared to the total population of the same age. We can distinguish different school enrollment rates as primary school enrollment and secondary school enrollment.

\subsubsection{Governance Variables}

- Rule and Law

The rule and law are defined by Kauffman (2008) as "the legal bond standard, whatever its source (legal rule, customary), its degree of generality (general, special rule), its scope (hard and fast rule, flexible ....)".

- $\quad$ Monetary variable M2

In this paper, we take the money supply within the meaning of M2 as a monetary variable. M2 is a variable which takes into account the influence of monetary policy on economic growth.

\section{Results}

To study the impact of external debt on economic growth, we used the VAR model. Assumed variables in this model are treated symmetrically so that each of them is explained by its own past values. According to Cunningham (1993), it is possible to treat the outstanding debt and the debt service as inputs in the neoclassical production function. Therefore, the model to be studied takes the following form:

$$
G D P=\alpha_{0}+\alpha_{1} E D+\alpha_{2} I+\alpha_{3} M 2+\alpha_{4} T O+\alpha_{5} R L+\alpha_{6} S+\alpha_{7} S D+\varepsilon
$$

Where:

GDP: economic growth rate,

ED: outstanding debt,

I: investment rate as a percentage of GDP,

M2: money supply within the meaning of M2,

TO: trade openness,

RL: rules and laws,

S: schooling rate,

SD: service debt in relation to exports of goods and services.

The estimated VAR model requires stationarity of the series. When two variables are non-stationary, we pass to the study of cointegration to test the existence of a long-term relationship. The tests used to determine the stationarity of variables are Augmented Dickey-Fuller (ADF) and Kowski- Philips-Schmidt-Shin (KPSS).

\subsection{Stationarity Test}

Before making our econometric study, we test the stationarity of variables by the test of Augmented Dickey-Fuller (ADF) and Philips-Peron (PP). $\mathrm{X}$ is a variable, we pose the following assumptions:

- H0: Xt is stationary when the statistic $\mathrm{T}$ is less than the critical value at the $5 \%$ threshold.

- $\mathrm{H} 1: \mathrm{Xt}$ is not stationary when the statistic $\mathrm{T}$ is greater than the critical value at the $5 \%$ threshold.

The results of the tests on the variables are shown in Tables 2, 3, 4 and 5. 
Table 2. Results of the stationary test variables (Augmented Dicky-Fuller in level)

\begin{tabular}{|c|c|c|c|}
\hline Variables & ADF statistical Test & Critical Value (5\%) & hypothesis retained \\
\hline GDP & -7.014 & -1.95 & $\mathrm{H} 0$ \\
\hline Outstanding debt & -1.35 & -1.95 & $\mathrm{H} 1$ \\
\hline Investment & -2.98 & -1.95 & $\mathrm{H} 0$ \\
\hline M2 & 2.39 & -1.95 & H1 \\
\hline Trade Openness & -1.35 & -1.95 & H1 \\
\hline Rules and law & -1.36 & -1.95 & $\mathrm{H} 1$ \\
\hline Schooling & 2.81 & -1.95 & $\mathrm{H} 1$ \\
\hline Debt Service & -1.66 & -1.95 & $\mathrm{H} 1$ \\
\hline
\end{tabular}

Source: Authors, Eviews Version 6.

Table 3. Results of the stationary test variables (Philips-Peron in level)

\begin{tabular}{lccc}
\hline Variables & Statistical Test ADF & Critical Value (5\%) & hypothesis retained \\
\hline GDP & -5.01 & -1.95 & H0 \\
Outstanding debt & -1.12 & -1.95 & $\mathrm{H} 1$ \\
Investment & -2.98 & -1.95 & $\mathrm{H} 0$ \\
M2 & 0.40 & -1.95 & $\mathrm{H} 1$ \\
Trade Openness & -1.25 & -1.95 & $\mathrm{H} 1$ \\
Rules and law & 1.71 & -1.95 & $\mathrm{H} 1$ \\
Schooling & 1.95 & -1.95 & $\mathrm{H} 1$ \\
Debt Service & -1.52 & -1.95 & $\mathrm{H} 1$ \\
\hline
\end{tabular}

Source: Authors, Eviews Version 6.

From the results identified in the Tables 2 and 3, we find that the two variables (GDP and investment) are stationary in level in the two tests. Their critical values are greater than their associated statistical values. For the other variables, they are non-stationary in level, and we apply the stationary tests in first difference.

Table 4. Results of the stationary test variables (ADF first difference)

\begin{tabular}{lccc}
\hline Variables & ADF statistic & Critical Value 5\% & hypotheses retained \\
\hline Outstanding debt & -4.18 & -1.95 & H0 \\
M2 & -3.52 & -1.95 & H0 \\
Trade openness & -5.40 & -1.95 & H0 \\
Rule and Law & -3.36 & -1.95 & H0 \\
Schooling & -2.05 & -1.95 & H0 \\
Debt service & -5.90 & -1.95 & H0 \\
\hline
\end{tabular}

Source: Authors, Eviews Version 6.

Table 5. Results of the stationary test variables (Philips-Peron first difference)

\begin{tabular}{|c|c|c|c|}
\hline Variables & ADF statistic & Critical Value $5 \%$ & hypotheses retained \\
\hline Outstanding debt & -4.99 & -1.95 & $\mathrm{H} 0$ \\
\hline M2 & -5.57 & -1.95 & $\mathrm{HO}$ \\
\hline Trade openness & -7.92 & -1.95 & $\mathrm{H} 0$ \\
\hline Rule and Law & -4.10 & -1.95 & $\mathrm{HO}$ \\
\hline Schooling & -3.95 & -1.95 & $\mathrm{HO}$ \\
\hline Debt service & -5.90 & -1.95 & $\mathrm{HO}$ \\
\hline
\end{tabular}

Source: Authors, Eviews Version 6.

The test results put in Tables 4 and 5 show that all variables are stationary in first difference. This leads to consider the possibility of the existence or not of a cointegration relationship between these variables. 


\subsection{Cointegration Test}

The results of stationarity tests of Augmented Dickey-Fuller (ADF) and Kowski-Philips-Shin (KPSS) show that the variables of outstanding debt, M2, trade openness, rule and law, schooling and debt service are stationary at first difference, which leads us to test the existence of a cointegration relationship based on the approach of Johanson. The number of delays is equal to one coinciding at least of criteria AIC and HQ.

\subsection{Test of Johansen}

The cointegration test proposed by Johanson is based on two tests: test of the maximum Eigen value and trace test to determine the existence of a cointegration relationship.

The test of the maximum Eigen value:

- H1: When the maximum Eigen value test is greater than the critical value at the $5 \%$ level, there is a cointegration relationship.

- H2: The opposite.

Table 6. Test of the maximum Eigen value

Unrestricted Cointegration rank test (Maximum Eigen value)

\begin{tabular}{lllll}
\hline Hypothesized NO of CE(S) & Eigen value & Max-Eigen statistic & Critical value (5\%) & Prob ** \\
\hline None* & 0.826475 & 50.7915 & 30.43961 & 0.0001 \\
\hline
\end{tabular}

Source: Authors, Eviews Version 6.

We see from Table 6 that the maximum Eigen value is greater than the critical value $(50.79>30.43)$, which means that there is a Cointegration relationship.

The trace test, which is summarized in Table 7, lets us know also if there is a Cointegration relationship or not. When the value of the trace test is greater than the critical value, then there is a cointegration relationship. In the opposite case, there is an absence of cointegration relationship.

Table 7. Trace test, unrestricted cointegration rank test (trace)

\begin{tabular}{|c|c|c|c|c|}
\hline Hypothesized NO of $\mathrm{CE}(\mathrm{S})$ & Eigen value & Trace statistic & Critical value $(5 \%)$ & Prob ** \\
\hline None* & 0.826475 & 92.798866 & 60.06141 & 0.0000 \\
\hline
\end{tabular}

Source: Authors, Eviews Version 6.

The results of the cointegration test show that the trace statistic value exceeds the critical value at the 5\% threshold $(92.79>60.06)$, which means that there is a long-term relationship between the stationary variables of order 1 .

To have more reliable estimates for the dynamic relationship between the different variables of the model, we use the error correction model (VECM).

\subsection{Error Correction Model (VECM)}

The estimated error correction model to determine the next long-term relationship is as follows:

$$
\begin{array}{r}
L n G D P=-0.191 E D+0.0781 I-0.198 M 2-0.776 T O-10.53 R L+0.916 S-0.743 D S \\
(-2.076) \quad(0.275) \quad(-1.01) \quad(-6.92) \quad(-7.72) \quad(7.73) \quad(-2.73)
\end{array}
$$

This result shows that investment is an important variable for growth in Tunisia. Indeed, a high rate of investment increases growth rate, which is consistent with the theory that the development of a country depends on the efforts made in terms of productive investment.

Also, the variable schooling takes a positive sign in the model, which means that when this rate increases, economic growth improves. When a population is well educated, they can improve the economic growth by entrepreneurial culture of the educated classes.

Regarding trade openness and M2, their effects on economic growth in Tunisia are negative. This result can be interpreted by the fact that Tunisia is an importing country, which increases the outflow of foreign exchange to 
pay imports and consequently leads to a decrease in the money supply. Furthermore, Tunisian exports have no significant value in the world market despite the important degree of integration of Tunisia in the world economy. The negative sign of trade openness is explained also by the value of the currency inflows of exports, which is insignificant. The rule and law variable takes also a negative sign in the model, which means that the quality of institutions in Tunisia still needs some improvements.

Also, the estimated error correction model shows that external debt in Tunisia affects negatively economic growth. The coefficients related to its two indicators (outstanding debt and debt service) are negative. This result can be explained differently. Investment and gross fixed capital formation are linked to debt service, that's why a higher payment for this service can influence the returns of productive investment and discourage capital formation. This is why we find that the variable of the debt service affects significantly and negatively economic growth. The payment of debt service decreases investment and impedes economic growth. In Tunisia, debt is used for projects which have social aspects. An increasing variation in debt service leads to a decreased ability of the State to invest, which leads to a decreasing variation of economic growth.

Like most developing countries, Tunisia can not do better without debt. The problem is not a debt problem in itself, but we have a problem concerning the use of this debt. Debt is allocated to activities with low value added and low profitability. These activities are not able to hire labor and reduce the unemployment rate. In many cases, these projects are in deficit and cause erosion of borrowed resources.

\subsection{The Adjustment Coefficients}

Table 8. Adjustment coefficients

\begin{tabular}{lllllllc}
\hline Error correction & $\mathrm{D}(\mathrm{ED})$ & $\mathrm{D}(\mathrm{DS})$ & $\mathrm{D}(\mathrm{I})$ & $\mathrm{D}(\mathrm{M} 2)$ & $\mathrm{D}(\mathrm{TO})$ & $\mathrm{D}(\mathrm{RL})$ & $\mathrm{D}(\mathrm{S})$ \\
\hline Cointegration & -0.1916 & -0.4737 & 0.078 & -0.1987 & -0.7767 & -10.53 & 0.9169 \\
equation & $(-2.076)$ & $(-2.735)$ & $(-0.275)$ & $(-1.015)$ & $(-9.265)$ & $(-7.721)$ & $(-7.736)$ \\
\hline
\end{tabular}

Source: Authors, Eviews Version 6.

According to Table 8 , the variables that have a negative and significantly coefficients are characterized by their return to long-term equilibrium. While variables of investment rate and enrollment rate have not this characteristic of long-term return to equilibrium.

\subsection{The Short Term Relationship}

The main objective of this test is to study the existence of external debt impact on growth variables at the beginning of the period, and afterwards we will see if there is a change or not in the impact.

Table 9. Short term relationship between external debt and economic growth

\begin{tabular}{ccccccccc}
\hline Error Correction: & $\mathrm{D}(\mathrm{GDP})$ & $\mathrm{D}(\mathrm{ED})$ & $\mathrm{D}(\mathrm{DS})$ & $\mathrm{D}(\mathrm{I})$ & $\mathrm{D}(\mathrm{M} 2)$ & $\mathrm{D}(\mathrm{TO})$ & $\mathrm{D}(\mathrm{RL})$ & $\mathrm{D}(\mathrm{S})$ \\
\hline CointEq1 & 0.039447 & -0.337697 & -0.162584 & 0.132733 & -0.231546 & -0.677985 & -0.016576 & -0.137453 \\
& $(0.16584)$ & $(0.25856)$ & $(0.14967)$ & $(0.08033)$ & $(0.06779)$ & $(0.36089)$ & $(0.01764)$ & $(0.08763)$ \\
& {$[0.23785]$} & {$[-1.30608]$} & {$[-1.08626]$} & {$[1.65233]$} & {$[-3.41545]$} & {$[-1.87862]$} & {$[-0.93960]$} & {$[-1.56858]$} \\
$\mathrm{D}(\mathrm{GDP}(-1))$ & -0.629995 & 0.062338 & 0.061333 & -0.050684 & 0.124376 & 0.659019 & -0.004380 & 0.005827 \\
& $(0.20916)$ & $(0.32609)$ & $(0.18876)$ & $(0.10131)$ & $(0.08550)$ & $(0.45515)$ & $(0.02225)$ & $(0.11052)$ \\
& {$[-3.01206]$} & {$[0.19117]$} & {$[0.32492]$} & {$[-0.50028]$} & {$[1.45470]$} & {$[1.44791]$} & {$[-0.19688]$} & {$[0.05272]$} \\
D (ED(-1)) & -0.048972 & 0.278920 & -0.003810 & -0.127597 & -0.091363 & 0.030393 & 0.002079 & -0.034698 \\
& $(0.17288)$ & $(0.26953)$ & $(0.15602)$ & $(0.08374)$ & $(0.07067)$ & $(0.37620)$ & $(0.01839)$ & $(0.09135)$ \\
& {$[-0.28327]$} & {$[1.03486]$} & {$[-0.02442]$} & {$[-1.52375]$} & {$[-1.29282]$} & {$[0.08079]$} & {$[0.11305]$} & {$[-0.37985]$} \\
D (DS(-1)) & 0.250034 & -0.033881 & -0.231229 & -0.145353 & 0.032397 & -0.122220 & -0.019361 & -0.093152 \\
& $(0.26784)$ & $(0.41757)$ & $(0.24172)$ & $(0.12974)$ & $(0.10949)$ & $(0.58285)$ & $(0.02849)$ & $(0.14152)$ \\
& {$[0.93353]$} & {$[-0.08114]$} & {$[-0.95658]$} & {$[-1.12039]$} & {$[0.29590]$} & {$[-0.20969]$} & {$[-0.67954]$} & {$[-0.65822]$} \\
D (I(-1)) & 0.196005 & -0.743162 & 0.510645 & 0.077456 & 0.021840 & 0.256634 & 0.022905 & 0.231660 \\
& $(0.45642)$ & $(0.71158)$ & $(0.41192)$ & $(0.22108)$ & $(0.18658)$ & $(0.99323)$ & $(0.04855)$ & $(0.24116)$ \\
& {$[-0.42944]$} & {$[1.04438]$} & {$[1.23967]$} & {$[0.35035]$} & {$[0.11706]$} & {$[0.25838]$} & {$[0.47177]$} & {$[0.96059]$} \\
D (M2(-1)) & -0.187889 & -0.307583 & 0.242960 & 0.324001 & 0.335147 & 0.708934 & -0.033636 & -0.368426 \\
& $(0.43850)$ & $(0.68365)$ & $(0.39575)$ & $(0.21240)$ & $(0.17925)$ & $(0.95424)$ & $(0.04665)$ & $(0.23170)$ \\
& {$[-0.42848]$} & {$[-0.44991]$} & {$[0.61392]$} & {$[1.52541]$} & {$[1.86969]$} & {$[0.74293]$} & {$[-0.72110]$} & {$[-1.59011]$} \\
\hline
\end{tabular}




\begin{tabular}{lllllllll}
\hline D (TO (-1)) & -0.070407 & 0.183597 & -0.090595 & -0.097109 & 0.125141 & 0.129998 & 0.000658 & 0.027246 \\
& $(0.11609)$ & $(0.18099)$ & $(0.10477)$ & $(0.05623)$ & $(0.04745)$ & $(0.25262)$ & $(0.01235)$ & $(0.06134)$ \\
& {$[-0.60649]$} & {$[1.01442]$} & {$[-0.86471]$} & {$[-1.72698]$} & {$[2.63707]$} & {$[0.51460]$} & {$[0.05328]$} & {$[0.44418]$} \\
D (RL (-1)) & -0.400902 & 2.337606 & 3.130103 & -1.880747 & 2.550280 & 1.993729 & 0.176020 & 2.350361 \\
& $(2.75776)$ & $(4.29948)$ & $(2.48888)$ & $(1.33580)$ & $(1.12732)$ & $(6.00122)$ & $(0.29336)$ & $(1.45715)$ \\
& {$[0.14537]$} & {$[0.54369]$} & {$[1.25764]$} & {$[-1.40795]$} & {$[2.26225]$} & {$[0.33222]$} & {$[0.60002]$} & {$[1.61298]$} \\
D (S (-1)) & 0.541692 & -0.168664 & 0.155874 & 0.073794 & -0.345355 & -0.831900 & 0.027134 & 0.020623 \\
& $(0.42680)$ & $(0.66541)$ & $(0.38519)$ & $(0.20673)$ & $(0.17447)$ & $(0.92877)$ & $(0.04540)$ & $(0.22551)$ \\
\hline
\end{tabular}

Source: Authors, Eviews Version 6.

In the short term, economic growth is negatively and significantly influenced by external debt, since outstanding debt and debt service have a significant impact according to results of short-term parameters of nullity of tests applied to the GDP growth rate.

\subsection{Analysis of Causality and Impulse Test}

\section{- Causality Test}

On the theoretical level, the study of the direction of causality between the different variables of the model is essential to develop an optimized economic policy and make predictions.

From an econometric point of view, the analysis of the direction of causality is generally performed to improve forecasting. With reference to Granger, the variable $\mathrm{X}$, for example, causes the variable $\mathrm{Y}$ if the knowledge of the past of the first variable leads to improve forecasting of the second variable.

According to Grellet (2003), causality can be formalized as follows: a variable Xt has Granger causality on a variable $\mathrm{Yt}$ if the whole past of $\mathrm{X}$ variables improves the prediction of $\mathrm{Y}$ relative to a regression on past values of Y. At this level, we have four possible cases:

- If all coefficients are significantly different from zero, then the causality between $\mathrm{X}$ and $\mathrm{Y}$ is bilateral.

- If the coefficients are not significantly different from zero, there is no causal relationship between the variables.

- If the coefficients are significantly different from zero and the coefficients are not significantly different from zero, then the causality is from $\mathrm{X}$ to $\mathrm{Y}$.

- If the coefficients are not significantly different from zero and the coefficients are significantly different from zero, then the causality is from $\mathrm{Y}$ to $\mathrm{X}$.

The causality test allows us to verify whether there is or not a causal relationship between the variables studied. In our study, we will rely on debt and growth variables and to do so, we test the following assumptions:

- H0: No causal relationship between variables when the probability is less than $10 \%$.

- H1: Causal relationship between variables when the probability is greater than $10 \%$.

Table 10. Results of Granger causality test

\begin{tabular}{lcc}
\hline Causal Sens & F-Statistics & Probability \\
\hline Outstanding debt does not granger cause GDP growth. & 2.35332 & 0.0319 \\
GDP growth does not granger cause outstanding debt. & 1.35394 & 0.0506 \\
Debt service does not granger cause GDP growth. & 1.01802 & 0.0183 \\
GDP growth does not granger cause debt service & 0.60923 & 0.0391 \\
Outstanding debt does not granger cause Investment & 6.61449 & 0.0133 \\
Investment does not granger cause Outstanding debt & 13.5418 & 0.0006 \\
Service debt does not granger cause Investment & 10.2202 & 0.0025 \\
Investment does not granger cause service debt & 8.99879 & 0.0043 \\
\hline
\end{tabular}

Source: Authors, Eviews Version 6.

Note. For further information, please refer to Appendix A.

From Table 10, the causality test shows that the outstanding debt does not cause the GDP growth rate with a probability of $3.19 \%$ and the growth rate of GDP does not cause the outstanding debt with a probability equal to 
$5.06 \%$, meaning the rejection of null hypothesis. The outstanding debt impedes Tunisian economic growth.

Similarly, the debt service does not cause the GDP growth rate with a probability of $1.83 \%$, and the GDP growth rate does not cause debt service with a probability equal to $3.91 \%$, meaning the rejection of null hypothesis. The service debt impedes also Tunisian economic growth.

The outstanding debt does not cause investment rate with a probability of $1.33 \%$, and the investment rate does not cause the outstanding debt with a probability equal to $0.06 \%$, meaning the rejection of null hypothesis. The service debt hinders investment.

The debt service does not cause the investment rate with a probability equal to $0.25 \%$, and the investment rate does not cause the debt service with a probability of $0.43 \%$, meaning the rejection of null hypothesis. The service debt hinders also investment.

The rejection of the null hypothesis, which consists that the debt service does not cause the investment rate, confirms theoretical works that emphasize the importance of debt service in the choice of investors. The external debt service reduces investment and constitutes an obstacle for economic growth. The Tunisian economy is very sensitive to any change in the debt ratio. That's why, Tunisia should lead a good external debt management strategy. This is not only limited to the repayment of debt service but also knowing how to reduce it. The authorities should increase exports to strengthen its external payment capacity and further reduce the ratio of debt service.

\section{- Pulse analysis (identification of impacts)}

The analysis of impulse response functions is used to measure the impact of a shock on the variables of the model and to pick out the effect of an innovation on current and future values of variables. Impulse response functions related to the effects of the shocks of outstanding debt and external debt service on economic growth are given respectively in these two figures.
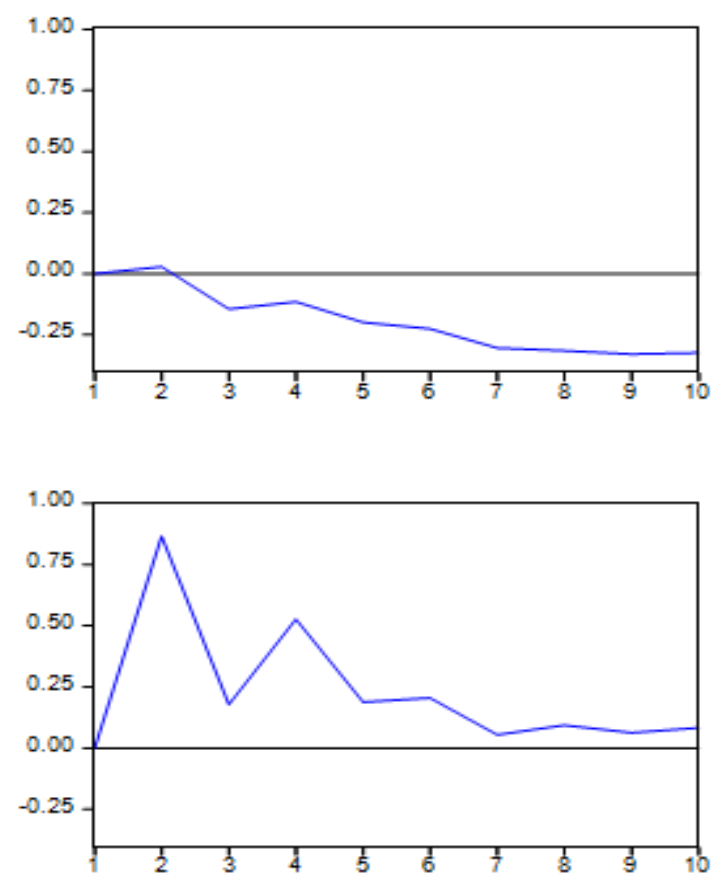

Figure 1. Response of GDP growth to shocks of outstanding debt and debt service

An increase in the external debt ratio affected the economic growth rate which decreased from the second year. A shock on the debt ratio affected immediately and negatively the economic growth and other variables such as investment which decreases.

These negative results confirm the theoretical predictions of the effect of external debt which constitutes a burden impeding investment and economic growth. Too much debt leads to discouragement of investment, which harms long term economic growth. 


\section{Discussion}

The purpose of this paper is to study the influence of external debt on investment and economic growth in Tunisia. In this research, we have used annual data related to Tunisian economy during the period from 1961 to 2011. The model served is the vector autoregressive model (VAR).

The empirical results that we found confirm hypothesis two of the negative effect of the external debt on the economic growth. Precisely, in short-term, outstanding debt and debt service in relation to exports of goods and services do not cause economic growth. In long term, the external debt service impedes economic growth. The amounts to be paid every year for both principal and interest are deducted from funds devoted to investment, which consequently decreases and slows Tunisian's economic growth. This conclusion supports the findings of Bolanle et al. (2015), Ajayi and Oke (2012), Athens and Malik (2012), Atique and Kamran (2012), Safdari and Mehrizi (2011), Cordella et al. (2005), Patillo et al. (2004), etc.

This negative effect of external debt does not mean that Tunisia should not borrow. The problem is not a debt problem in itself, but it concerns the use of this debt. Debt is allocated to activities with low added value and profitability. These activities are traditional activities that do not create wealth, correspond with competitive advantages of the country and employ the qualified workforce. Therefore, the unemployment rate of graduates increases regularly. Moreover, a significant share of borrowed funds are intended to pay the salaries of the public sector, that have represented more than a third of the state budget in recent years. Then, external debt did not help the country to develop because those salaries went into consumption of some imported goods that are not produced in the home market.

In this article, we do not suggest the cancellation of external debt, but we offer some solutions to limit its perverse effects. In fact, the state must rationalize the use of external indebtedness. It should give priority to financing new productive sectors that represent the competitive advantages of the country. Tunisian government must reallocate its exterior resources to sectors with high added value and export sectors.

Tunisia is a country that suffers from tax evasion. The state must reform its tax system, since as such it fails to help the government collect additional resources that can reduce the amount of external debt. Studies recently made by financial experts have suggested that Tunisia can obtain additional resources in the order of 5000MDT if it opts for a deep tax reform. This value is equal to nearly the value of the country's annual debt.

\section{References}

Abdelhadi, A. (2013). Debt and Economic Growth in Developing Countries: Jordan as a Case Study. International Journal of Economics and Finance, 7(3).

Abu, S. et al. (2015). The impact of external debt on economic growth: Empirical evidence from highly indebted poor countries. The University of Western Australia E A Selvanathan, Griffith Business School, Griffith University, and Saroja Selvanathan, Griffith Business School, Griffith University. Retrieved from http://www.business.uwa.edu.au/_data/assets/pdf_file/0004/2712244/15.10-Siddique

Ajayi, L. B., \& Oke, M. O. (2012). Effect of external debt on economic growth and development of Nigeria. International Journal of Business and Social Science, 3(12).

Atique, R., \& Kamran, M. (2012). Impact of domestic and external debt on the economic growth of Pakistan. World Applied Sciences Journal, 20(1), 120-129.

Bolanle, A. et al. (2015). External debt or foreign direct investment: Which has greater significant economic impact on Nigeria. European Scientific Journal, 11(19), 1857-7881. Retrieved from http://eujournal.org/index.php/esj/article/view/5937

Chamki, F. (2010). Quel rôle joue la dette en Tunisie ou bien handicap du développement (CATDM-Tunisie). Institut Africain de Développement Economique et de Planification (IDEP), Tunisie. Retrieved from $\mathrm{http} / / / \mathrm{cadtm}$. org/Quel-role-joue-la-dette-exterieure?

Dedehouanou, S. (2009). Chocs asymétriques et ajustement en Union Economique et Monétaire Ouest Africaine (UEMOA). Thèse De Doctorat en Sciences Economiques, Université Cheikh Anta Diop de Dakar.

Evan, L. et al. (2015). External debt and economic growth nexus: Evidence from Malaysia, Thailand and Philippines. $16^{\text {th }}$ International Academic Conference, Amsterdam.

Granger, E. (1969). Investigating Causal Relations by Econometric Models and Cross-spectral Methods C. W. J. Granger Gaussé et Al, Christophes A Sims Et La Representation VAR Université De Grenoble. http://dx.doi.org/10.2307/1912791 
Jean, P. (1970). La colonisation et l'Agriculture Européenne en Tunisie depuis 1881. Publication: Mouton 1962, Description.

Karagol, E. (2004). Is There Externality from the Government Sector and the Non-Government Sector? A Feder Model Approach. Kocaeli Üniversitesi Sosyal Bilimler Enstitüsü Dergisi, 157-168. Retrieved from https://www.researchgate.net/publication/265495321_Is_There_Externality_from_the_Government_Sector _and_the_Non-Government_Sector_A_Feder_Model_Approach

Kauffman, D., \& Kraay, A. (2008). Governance Matters VII, Aggregate And Individual Governance Indicators. Global Governance program, World Bank. Retrieved from https://openknowledge.worldbank.org/bitstream/handle/10986/4170/WPS4978.pdf?sequence=1

Lubrano, (2007). Modèles VAR structurels et modèles à équations Simultanées. Economica.

Mehdi, K. (2013). La dette extérieure de la Tunisie entre 1970-2010. Du Mensonge à L'appauvrissement de la Tunisie, Centre de Recherche et D'information pour le Développement, Mars.

Moga, T., Helian, X., \& Igor, M. (2016). The Impact of external debt and foreign direct investment on economic growth: Empirical Evidence from Tanzani. http://dx.doi.org/10.5430/ijfr.v7n2p154

Ojjo, I., \& Oshikoya, K. (1995). Who report regression results for nineteen African countries using data from 1970-91. Pooled into Four Period Averages.

Onuorah, A. (2015). Deficit financing and the growth of Nigeria economy. International Journal of Management Sciences and Business Research, 3(2). Retrieved from http://eujournal.org/index.php/esj/article/view/702

Robert. J. (1995). Inflation and economic growth. Annals of Economics and Finance, Society For AEF. Retrieved from http://www.nber.org/papers/w5326

Sims, C. (1980). Macro economics and reality. Econometrica, 1-48. http://dx.doi.org/10.2307/1912017

Suna, K. (2015). The Relationship between external debt and economic growth in Turkey. Proceedings of the Second European Academic Research Conference On Global Business, Economics, Finance and Banking, 3-5 July, 2015 Paper. Retrieved from http://globalbizresearch.org/Swiss_Conference/pdf/Z581.pdf

Uzun, A., \& Cagatay, K. (2012). The Impacts of external debt on economic growth in transition Economies. Chinese Business Review, 11(5), 491-499.

Zaman, R., \& Arslan, M. (2014). The Role of external debt on economic growth: Evidence from Pakistan economy. Journal of Economics and Sustainable Development. Retrieved From http://papers.ssrn.com/sol3/papers.cfm?abstract_id=2532275

\section{Appendix}

\section{Causality}

pairwise granger causality tests

date: $10 / 18 / 13$ time: $16: 00$

sample: 19612011

lags: 1

\begin{tabular}{|c|c|c|c|}
\hline null hypothesis: & obs & f-statistic & prob. \\
\hline Investment does not granger cause GDP & 49 & 2.70393 & 0.1069 \\
\hline GDP does not granger cause investment & & 5.80891 & 0.0200 \\
\hline M2 does not granger cause GDP & 49 & 6.39535 & 0.0149 \\
\hline GDP does not granger cause $\mathrm{m} 2$ & & 1.04000 & 0.3132 \\
\hline Trade openness does not granger cause GDP & 49 & 3.94908 & 0.0529 \\
\hline GDP does not granger cause Trade openness & & 0.07324 & 0.7879 \\
\hline Rules and law does not granger cause GDP & 31 & 0.28965 & 0.5947 \\
\hline GDP does not granger cause rules and law & & 0.90938 & 0.3484 \\
\hline Schooling does not granger cause GDP & 49 & 2.85650 & 0.0978 \\
\hline GDP does not granger cause schooling & & 0.79209 & 0.3781 \\
\hline Debt service does not granger cause GDP & 49 & 1.01802 & 0.0183 \\
\hline GDP does not granger cause debt service & & 0.60923 & 0.0391 \\
\hline
\end{tabular}


M2 does not granger cause investment

Investment does not granger cause M2

Trade openness does not granger cause investment

Investment does not granger cause trade openness

Rules and law does not granger cause investment

Investment does not granger cause rules and law

Schooling does not granger cause investment

Investment does not granger cause schooling

Debt service does not granger cause investment

Investment does not granger cause debt service

Trade openness does not granger cause M2

M2 does not granger cause Trade openness

Rules and law does not granger cause M2

M2 does not granger cause rules and law

Schooling does not granger cause M2

M2 does not granger cause schooling

Debt service does not granger cause M2

M2 does not granger cause debt service

Rules and law does not granger cause trade openness

Trade openness does not granger cause Rules and law

$\underline{\text { schooling does not granger cause trade openness }}$
50

50

31

50

50

50

31

50

50

31

(1)
0.3877

0.3016

0.9161

0.3169

1.02351

0.3106

$2.04439 \quad 0.1594$

$6.69254 \quad 0.0128$

$10.2202 \quad 0.0025$

$8.99879 \quad 0.0043$

$0.01290 \quad 0.9101$

$6.67939 \quad 0.0129$

$\begin{array}{ll}0.89321 & 0.3527\end{array}$

$0.19135 \quad 0.6652$

$3.33125 \quad 0.0743$

$0.22940 \quad 0.6342$

$\begin{array}{ll}3.45210 & 0.0694\end{array}$

$\begin{array}{ll}0.71008 & 0.4037\end{array}$

$1.76285 \quad 0.1950$

$\begin{array}{ll}0.08880 & 0.7679\end{array}$

$\begin{array}{ll}0.87209 & 0.3551\end{array}$

\section{Copyrights}

Copyright for this article is retained by the author(s), with first publication rights granted to the journal.

This is an open-access article distributed under the terms and conditions of the Creative Commons Attribution license (http://creativecommons.org/licenses/by/3.0/). 